\title{
Correction: Establishment and reinforcement of the National Reference Centers for Human Microbiology in Belgium
}

Gaëtan Muyldermans*, Amber Litzroth, Geneviève Ducoffre, Sophie Quoilin and the Medical-Technical Advisory Board

\section{Correction}

The correct names of the authors of this article [1] are Gaëtan Muyldermans, Amber Litzroth, Geneviève Ducoffre, Sophie Quoilin and the Medical-Technical Advisory Board.

The Publisher and authors apologize to the readers for the inconvenience caused.

Received: 10 April 2013 Accepted: 21 April 2013

Published: 22 April 2013

\section{Reference}

1. Muyldermans G, Litzroth A, Ducoffre G, Quoilin S, the Medical-Technical

Advisory Board: Establishment and reinforcement of the National

Reference Centers for Human Microbiology in Belgium. Archives of Public Health 2012, 70:16. 22 June 2012.

\section{doi:10.1186/0778-7367-71-8}

Cite this article as: Muyldermans et al:: Correction: Establishment and

reinforcement of the National Reference Centers for Human

Microbiology in Belgium. Archives of Public Health 2013 71:8.

* Correspondence: gaetan.muyldermans@wiv-isp.be

Institute of Public Health, Public Health and Surveillance, J. Wytsmanstreet 14 1050, Brussels, Belgium

\section{Submit your next manuscript to BioMed Central} and take full advantage of:

- Convenient online submission

- Thorough peer review

- No space constraints or color figure charges

- Immediate publication on acceptance

- Inclusion in PubMed, CAS, Scopus and Google Scholar

- Research which is freely available for redistribution

Submit your manuscript at www.biomedcentral.com/submit
C Biomed Central 